\title{
RELIKTY ZANIKLYCH JEDNOSTEK OSADNICZYCH NA POGRANICZU MAZURSKO-MAZOWIECKIM. INTERDYSCYPLINARNY PROJEKT BADAWCZY
}

SŁowa Kluczowe: archeologia współczesności, geografia historyczna, Mazury, krajobraz kulturowy, zanikłe wsie, pamięć, osadnictwo wiejskie

KEYwORDS: archaeology of the contemporary past, historical geography, Masuria, cultural heritage, deserted villages, memory, rural settlement

\section{WPROWADZENIE}

Osadnictwo w południowej części Mazur, od wieków stanowiącej pogranicze terytoriów posiadających częściową i pełną niezależność, zdeterminowane zostało przede wszystkim przez czynniki polityczne. Tereny znajdujące się na obrzeżach tzw. Wielkiej Puszczy w średniowieczu były strategicznymi rubieżami, a zarazem słabo zaludnionym i trudno dostępnym obszarem pogranicza. Jego sieć osadniczą nakreśliły akcje kolonizacyjne rozpoczęte po 1422 roku (Białuński 2002: 22), podczas których lokowano pierwsze z historycznie znanych osad - wiele $\mathrm{z}$ nich przetrwało w podobnych lub znacznie zmienionych formach morfologicznych do dzisiaj. Z perspektywy współczesności, gwałtowne przemiany w mazurskim krajobrazie kulturowym, (które jeszcze się nie zakończyły!) stanowią pokłosie XX-wiecznych światowych konfliktów zbrojnych. Ciągłość osadnicza na pograniczu została w wielu miejscach przerwana - wsie opuszczone przez autochtoniczną ludność rozszabrowano po 1945 roku i nigdy już ich nie odbudowano. Ich relikty, nadal stosunkowo dobrze czytelne w przestrzeni, są świadectwem życia wielu lokalnych mazurskich społeczności, historii tej ziemi, wciąż częścią kulturowego krajobrazu. Jego wyjątkowość, wyrażająca się poprzez dzieje historyczne zapisane w strukturze materialnej, skłania do zadania wielu pytań badawczych, pośród nich także tych znajdujących miejsce w nurcie współczesnych badań osadniczych. Szczególną uwagę autorki przyku- 
wają zagadnienia związane $\mathrm{z}$ orientacją materialną $\mathrm{w}$ studiach krajobrazowych, mianowicie: jakie relikty poszczególnych założeń ruralistycznych współtworzą obecnie krajobraz? Jakim przekształceniom podlegają? Jaką historię można za ich pośrednictwem odczytać? ${ }^{1}$

Ujęte w powyższym skrócie rozważania stanowiły podstawę do podjęcia realizacji projektu badawczego, którego zasadniczym celem było dokonanie charakterystyki współczesnych reliktów zanikłych w XX wieku jednostek osadniczych pogranicza mazursko-mazowieckiego oraz określenie rodzaju i intensyfikacji przekształceń zachodzących w ich obrębie. Wyróżniono następujące cele szczegółowe:

- identyfikację i inwentaryzację terenową powierzchniowych materialnych pozostałości opuszczonych osad: reliktów zabudowy, ciągów komunikacyjnych, cmentarzy i innych niewymienionych;

- określenie rodzaju i intensyfikacji przemian zachodzących w obrębie opuszczonych osad na podstawie własnych obserwacji terenowych oraz przy wykorzystaniu materiałów i narzędzi teledetekcyjnych;

- określenie genezy i morfologii jednostek osadniczych;

- dokonanie oceny stopnia zachowania historycznych układów ruralistycznych oraz ich elementów morfologicznych.

Celem artykułu jest przedstawienie założeń wykonanego przez autorkę w 2017 roku projektu badawczego dotyczącego osadnictwa, które uległo zanikowi po 1945 roku na terenie pogranicza mazursko-mazowieckiego. Badania zrealizowano w konwencji interdyscyplinarnej, łączącej ścieżki badawcze archeologii współczesności i geografii historycznej. Rezultaty zastosowanego podejścia teoretyczno-metodycznego przedstawiono na przykładzie studium przypadku osady znajdującej się obecnie w stadium zaniku (wg klasyfikacji Szmytkie 2008), położonej na terenie pogranicza mazursko-mazowieckiego w powiecie piskim (woj. warmińsko-mazurskim).

\section{GŁówne Zalożenia Projektu BadawCZego. Metodyka badań}

Projekt został oparty na dotychczasowej praktyce w badaniach ruralistycznych z zakresu procesów depopulacji i zaniku osadnictwa oraz reliktów opuszczonych jednostek osadniczych prowadzonych przez badaczy reprezentujących dyscypliny: archeologię historyczną (w tym współczesności) oraz geografię historyczną. Autorka, projektując badania uwzględniła m.in. ostatnie dokonania czeskiego zespołu Pavla Vařeki, Miroslava Buraćinská, Petra Rožmberský,

${ }^{1}$ Projekt sfinansowano ze środków Studenckiego Grantu Badawczego Uniwersytetu Łódzkiego przyznanego autorce w 2017 roku, zrealizowanego pod opieką naukową dr hab. A. Marciniak-Kajzer prof. UŁ w Katedrze Archeologii Historycznej i Bronioznawstwa Instytutu Archeologii Uniwersytetu Łódzkiego. 
Renaty Veselá. Rezultatem jego działań jest praca Archeologie zaniklých středověkých vesnic na Rokycansku II (2008), będąca jednym z pierwszych opracowań, w którym przedstawiono wyniki kompleksowych badań dotyczących opuszczonych średniowiecznych osad. Przeprowadzono je z wykorzystaniem nowoczesnych narzędzi badawczych (m.in. skanowania laserowego i GIS) ${ }^{2}$. Sposób dokumentacji techniczno-rysunkowej autorka wzorowała również na zastosowanym przez Lukáša Funka w jego dysertacji doktorskiej (2013) dotyczącej osad zanikłych po 1945 roku. Analizy ukierunkowano zaś w dużej mierze na ścieżce morfogenetycznej praktykowanej przez historię i geografię historyczną (m.in. Koter 1994). W drugiej z wymienionych istotną rolę odgrywa stratygrafia krajobrazu, opierająca się na retrogresji, za pomocą której wydziela się poszczególne etapy rozwoju/zaniku struktur osadniczych (podobne, ale nie tożsame jest mające zastosowanie w studiach nad dziedzictwem pojęcie palimpsestu - m.in. Bailey 2007; Kijowska i in. 2011). Poza wiodącym w badaniach podejściem retrogresywnym, w wybranych przypadkach, dla których możliwe było zgromadzenie materiałów archiwalnych ukazujących stan struktur osadniczych dla danego momentu z przeszłości, zastosowano progresywną drogę analiz (np. przedstawione tutaj jako studium przypadku Sokoły Górskie) (zob. Szulc 1995: 23).

Badania nad zanikającym i zanikłym osadnictwem są doskonałym przykładem tego, jak zagadnienia pierwotnie eksplorowane przez jedną dyscyplinę, rozwijają się, rozszerzając swój zakres problemowy i stają się udziałem wielu nauk, jak wydawałoby się wąskospecjalistyczne badania z zakresu metrologii siedlisk i analizy struktury wewnętrznej jednostek osadniczych (m.in. Fokt, Legut-Pintal 2016). Struktury tak złożone, jak jednostki osadnicze, zawsze stanowily tematy badawcze predestynujące do analiz wieloaspektowych, prowadzonych w ten sposób już w pierwszej połowie XX wieku (np. archeologiczno-geograficzne ujęcie Thomasa Shepparda 1912, historyczno-gospodarcze analizy Maurice Beresforda 1954). Badania nad zanikłym historycznym osadnictwem wiejskim mają swoją długą tradycję, a ponieważ ramy artykułu nie pozwalają na jej szczegółowe przybliżenie, autorka poleca uwadze Czytelnika prace, w których dużą uwagę poświęcono tym zagadnieniom, pióra: Michaela Astona (1985), M. Beresforda, Johna Hursta (1972), Tomasza Figlusa (2016), Krzysztofa Fokta (2016), Anny Marciniak-Kajzer (2016).

Dotychczas na terenie Mazur, poza eksploracjami stricte historycznymi dotyczącymi procesów osadniczych, których wyniki publikowano szczególnie licznie na łamach „Komunikatów Mazursko-Warmińskich” (m.in. Białuński 1993; Kowalczyk 2003; Szultka 2004; Kostrzewa 2007) nie prowadzono szcze-

${ }^{2}$ Tożsamą metodykę badań nad opuszczonymi wsiami zastosowano również w opracowaniu pod redakcją P. Vařeki, P. Rožmberský (Středověká Krajina... 2009). 
gółowych badań nad obecnymi w krajobrazie reliktami zanikłych jednostek osadniczych ${ }^{3}$. Na obszar badań wyznaczono fragment pogranicza mazursko-mazowieckiego, znajdujący się w granicach powiatu piskiego. Jego zasięg dookreślono na podstawie analizy materiałów kartograficznych (głównie arkuszy Topographische Karte 1:25 000 z lat 1870-1945), której wyniki wskazały obszar największej koncentracji osad zanikłych. Spośród zidentyfikowanych 38 opuszczonych jednostek osadniczych i pozostających obecnie $\mathrm{w}$ ostatnim etapie depopulacji ${ }^{4}$ występujących $\mathrm{w}$ wyznaczonym pasie pogranicza ${ }^{5}$ wybrano 12 jednostek osadniczych potencjalnie najbardziej reprezentatywnych dla obszaru badań: Dłutowo, Sokoły Górskie, Lipnik, Paski Małe, Paski Wielkie, Piskorzewo, Przerośl, Wolisko Wielkie, Wądołek oraz leśniczówki: Eichental, Erdmannen, Henriettental.

Plan badań podzielono na 4 zasadnicze etapy:

1. Przygotowawczy;

2. Badania terenowe;

3. Kwerendy uzupełniające;

4. Opracowanie kameralne wyników badań

Etap przygotowawczy objął wstępne rozpoznanie terenów zanikłych wsi, dookreślenie obszaru badań oraz dokonanie kwalifikacji wsi do szczegółowych badań terenowych. Na tym etapie wykorzystano następująco:

- metodę retrogresywną - powszechnie stosowaną w geografii historycznej i badaniach archeologicznych, szczególnie na etapie rozpoznania obszaru badań; na podstawie źródeł historycznych i materiałów archeologicznych badacz wychodząc od czasów późniejszych, dokonuje charakterystyki wcześniejszych etapów osadnictwa (Arnold 1951: 57; Karsvall 2013); metoda ta została zastosowana m.in. w analizach arkuszy map: Topographische Karte (1:25 000), nazw miejscowych (szczególnie mikrotoponimicznych) na aktualnych mapach, literatury przedmiotu (m.in.: Korycka 1970; Białuński 2002);

- materiały teledetekcyjne - wstępnego rozpoznania przestrzeni zanikłych osad dokonano na podstawie analizy:

${ }^{3}$ Wyłączając badania powierzchniowe prowadzone w ramach AZP oraz projekt Zagubione wioski Puszczy Piskiej prowadzony od 2008 roku przez Stowarzyszenie Sadyba Mazury, pod kierownictwem Krzysztofa Worobca (który jest również w trakcie przygotowywania publikacji książkowej na temat zanikłych wsi Puszczy Piskiej).

${ }^{4}$ Spośród nich 33 to jednostki osadnicze całkowicie wyludnione, natomiast 5 znajduje się obecnie w ostatnim etapie depopulacji. Spośród osad całkowicie opuszczonych 24 zidentyfikowano jako wsie, osobno natomiast 9 jako leśniczówki.

${ }^{5} \mathrm{Na}$ potrzeby badań za obszar pogranicza przyjęto pas terenu w powiecie piskim wyznaczony za pośrednictwem ekwidystanty o wartości $10 \mathrm{~km}$, wytyczonej od granicy województwa warmińsko-mazurskiego. 
- obrazowań Numerycznego Modelu Terenu w formach: hillshade oraz hipsometrii o dynamicznej skali barw;

- fotointerpretacji porównawczej aktualnych i archiwalnych zdjęć lotniczych oraz ortofotomap.

Badania terenowe zostały przeprowadzone między 13 a 25 sierpnia 2017 roku, a zatem w czasie kulminacyjnym okresu wegetacyjnego, co pozwalało zaobserwować wyróżniki roślinne występujące na obszarze badań, ale jednocześnie stanowiło utrudnienie w prowadzeniu dokumentacji (o wadach i zaletach przeprowadzania badań w okresie wzrostu roślinności m.in. w: Sztampke 2014: 117-122). Zwiad terenowy obejmował kartowanie: identyfikację i inwentaryzację reliktów osad posiadających własną formę powierzchniową. Kartowanie zostało przeprowadzone w konwencji nieinwazyjnych badań terenowych (bez pozyskiwania zabytków ruchomych). Badania zaproponowane przez autorkę, nawiązują do idei prospekcji typu urban exploration (por. Kobiałka 2016), która realizowana zazwyczaj na terenach zurbanizowanych, zakłada dokonanie dokumentacji bez naruszania struktur stanowiących przedmiot zainteresowania badacza. W tym przypadku idea ta została zaaplikowana do badań zanikłego osadnictwa wiejskiego. Dokumentacja reliktów jednostek osadniczych została przeprowadzona przy użyciu: urządzenia pomiarowego GPS, tyczek pomiarowych oraz zaprojektowanych przez autorkę kart inwentaryzacyjnych:

- „karty inwentaryzacyjnej jednostki osadniczej” obejmującej m.in. charakterystykę reliktów: ciągów komunikacyjnych, terenów użytkowych, elementów fizjograficznych (m.in. rzeźby terenu, cieków wodnych, roślinności), przemian morfogenetycznych;

- karty inwentaryzacyjnej obiektu/zespołu obiektów” obejmującej m.in. opis fizykalny (wymiary, morfologię, widoczne na powierzchni materiały budulcowe, roślinność towarzyszącą); karta obejmuje także dokumentację techniczno-rysunkową;

- „karty inwentaryzacyjnej cmentarza” obejmującej m.in. opis: oznaczeń grobów, roślinności, ciągów komunikacyjnych.

Dla każdego ze zidentyfikowanych obiektów została sporządzona dokumentacja fotograficzna.

Opracowanie kameralne wyników badań obejmowało:

- zintegrowanie informacji w przestrzennej bazie danych GIS, która posłużyła syntetycznemu opracowaniu zagadnienia reliktów osad i zachodzących w ich obrębie przemian; główny moduł bazy stanowią warstwy skumulowane $\mathrm{w}$ banku informacji mapy opracowanej w środowisku Google Maps - umożliwiło to integrację danych w czasie rzeczywistym podczas wykonywania czynności terenowych; analizy szczegółowe zostały wykonane w programach: ArcGIS, Inkscape, AutoCAD; 
- w warunkach kameralnych przeprowadzono konsolidację specyfikacji techniczno-rysunkowej obiektów otrzymanej w warunkach terenowych $\mathrm{z}$ danymi LiDAR (zamówionymi w CODGiK w formacie LAS 1.2); integracja danych służyła m.in. stworzeniu przestrzennych modeli zinwentaryzowanych obiektów.

\section{STUDIUM PRZYPADKU - PRZESTRZEŃ ZANIKAJĄCEJ OSADY}

Sokoły Górskie obecnie są „wymierającą” jednostką osadniczą, położoną nad bezimienną strugą, dawniej nazywaną Kowalewer Fließ. W centralnej części siedliska znajduje się jedna zamieszkała, przedwojenna wiejska zagroda, na którą składają się dom, obora i wolno stojące szopy. Jej gospodarz dobrze pamięta, jak tuż po zakończeniu II wojny światowej osada przestawała istnieć. Jak wspominał, kilka zamieszkujących w Sokołach rodzin opuściło miejscowość tuż po 1945 roku. Zaledwie $1 \mathrm{~km}$ w linii prostej przez pola dzieli wieś od dawnej granicy Prus Wschodnich z II Rzeczpospolitą (ryc. 1). Miejscowości położone na samym pograniczu były obiektem grabieży, o czym też rozmówca wspominał mówiąc, że ,woleli rozbierać domy i przenosić je na dawną polską ziemię, niż zamieszkać tutaj na gotowym".

Osada, funkcjonująca dawniej również pod nazwami: Sokoloffzken, Sokollen am Berg (Sokoły pod Górą) i Falkendorf została założona w 1428 roku przez komtura bałgijskiego. Wówczas 30 łanów ziemi na prawie chełmińskim (po odnowieniu przywileju w XVI wieku na prawie magdeburskim) otrzymał Maciej Lisysun (Łysuń). W miejscowości w połowie XVI wieku funkcjonowała karczma. Wówczas wieś należała do pastora w Kumielsku (Białuński 2002: 25, 69, 72). W historii miejscowości istnieją luki, które trudno uzupełnić. Kolejne dane dotyczą już bowiem wieku XVIII. W 1737 roku założono w Sokołach szkołę, która w 1800 roku była jedną z placówek funkcjonujących pod patronatem królewskim. Uczęszczało do niej w tym czasie 38 uczniów (Korycka 1970: 174; Matuszewski 1980: 32). Pod koniec XIX wieku we wsi było 29 domów, zamieszkałych łącznie przez 164 osoby (Chlebowski, Walewski 1890, t. XI: 39). W 1939 roku Sokoły Górskie zamieszkiwało zaś nieco mniej, bo 149 osób (Korycka 1970: 174). Z informacji uzyskanych od ostatniego mieszkańca wsi wynika również, że w pierwszej połowie XX wieku w północnej części miejscowości, na wzniesieniu znajdowała się prywatna elektrownia założona przez jednego z gospodarzy, najprawdopodobniej oparta na konstrukcji znajdującego się tam wiatraka. Relacja jest zbieżna z archiwalnym zapisem kartograficznym - na mapie z 1936 roku, na terenie gospodarstwa położonego w północnej części osady umieszczono sygnaturę symbolizującą silnik wiatrowy (Zestawienie znaków topograficznych... 1925: 3).

\footnotetext{
${ }^{6} \mathrm{Z}$ rozmowy autorki z gospodarzem we wsi Sokoły $-22.08 .2017 \mathrm{r}$.
} 


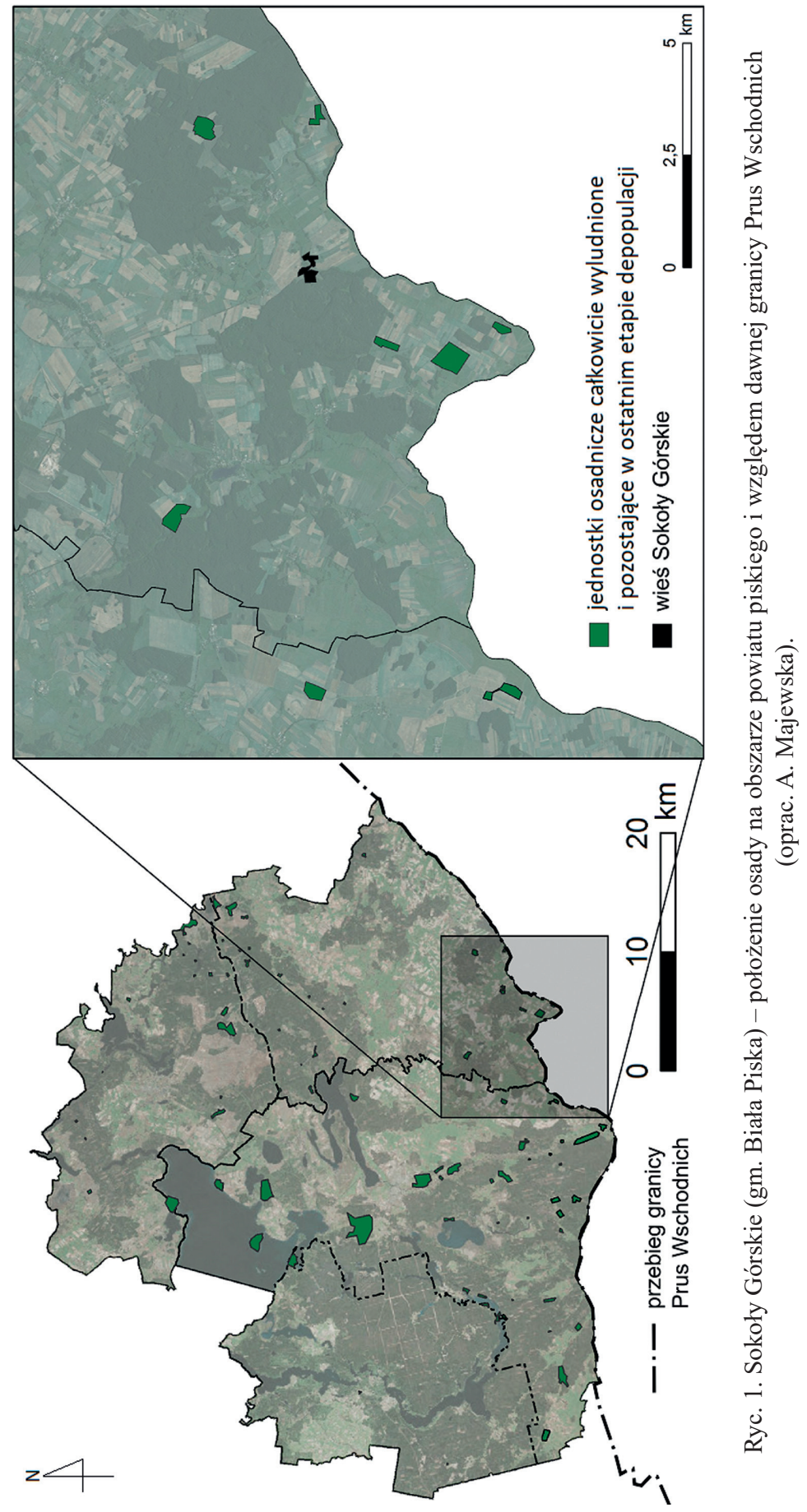


Rozmiary i charakter przekształceń horyzontalnej struktury krajobrazu wsi rozpoczętych jeszcze w pierwszej połowie XX wieku można ustalić m.in. na podstawie zestawienia archiwalnych materiałów kartograficznych, fotogrametrycznych zdjęć lotniczych i ortofotomap. Taką kompilację przedstawia ryc. 2. Obiekty, które zostały zaznaczone na rycinie zidentyfikowano głównie podczas fotointerpretacji kameralnej, stanowiącej zarówno formę wywiadu archeologicznego poprzedzającego nieinwazyjne, dokumentacyjne badania terenowe, jak i uzupełnienie dokonanej fotointerpretacji polowej (o metodach: Ciołkosz i in. 1999: 149-151). Na podstawie mapy topograficznej z 1936 roku oszacowano liczbę budynków znajdujących się wówczas we wsi na ok. 60, co w konfrontacji z danymi historycznymi (zob. powyżej) oznacza, że po uśrednieniu na jedną zagrodę wiejską składały się 2 budynki (według układów przestrzennych parceli zagrodowych widocznych na mapie, na jedno gospodarstwo mogło się w owym czasie składać od 2 do 4 budynków). W 1967 roku w Sokołach zamieszkałe były prawdopodobnie jeszcze 3 zagrody wiejskie (łącznie 8 budynków nakrytych dachem), kolejne zaś znajdowały się już w stadium daleko posuniętej destrukcji. Współcześnie we wsi funkcjonuje jedynie jedno, wspomniane już gospodarstwo. Relikty pozostałej zabudowy osiągają maksymalną wysokość 1,45 m od powierzchni gruntu (zob. ryc. 4). Wcięcia drogowe, poza głównym, użytkowanym jeszcze do komunikacji z pobliskimi miejscowościami, są właściwie nieczytelne w krajobrazie. W ciągu 50 lat znacznemu zatarciu uległ także układ pól - nadziały sąsiadujące z dawnymi siedliskami przestały być eksploatowane gospodarczo, przekształcając się w ugory. Część z nich stanowi naturalne łąki, na których obecnie wypasane jest bydło. Zaobserwowano znaczne zwiększenie procentowego udziału roślinności wysokiej na terenie wsi. Szczególnie obszar sąsiadujący z korytem cieku, znajdujący się na północ oraz na zachód od centrum osady uległ przekształceniu w las mieszany, w którego składzie dominuje olsza czarna i świerk pospolity oraz sosna zwyczajna (wiek drzewostanu - 54 lata, sosna do 83-123 lata) ${ }^{7}$ (w niektórych miejscach stopień pokrycia terenu przez drzewostany uległ zwiększeniu z 10 do 100\%). Sukcesja roślinności najintensywniej zaszła w obrębie porzuconych zagród, które stosunkowo szybko zostały zaanektowane przez roślinność synantropijną, np. apofity m.in.: perz właściwy oraz krzewy i drzewa owocowe. Stwarza to znaczne utrudnienie dla prowadzenia prospekcji terenowej, nawet w sezonie pozawegetacyjnym.

Interesującymi obiektami, stanowiącymi dawniej składowe krajobrazu, a współcześnie już nierozpoznawalnymi w terenie, są odczytywalne ze zdjęcia lotniczego pochodzącego z 1967 roku, linie transzei, okalające miejscowość od

${ }^{7}$ Skład gatunkowy drzewostanu: Bank Danych o Lasach: https://www.bdl.lasy.gov.pl/portal/ mapy (dostęp: 23.10.2017). 

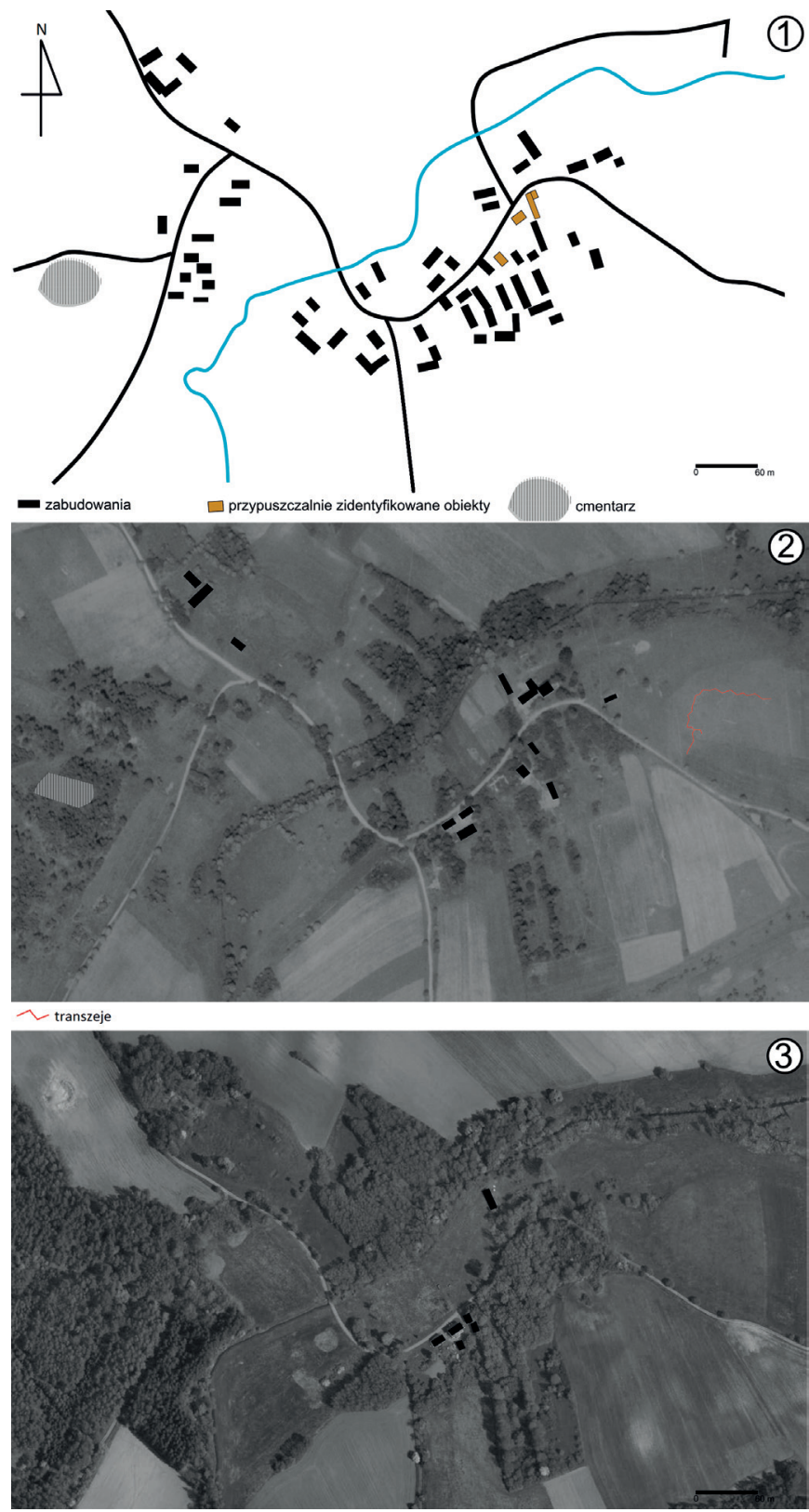

Ryc. 2. Proces zaniku wsi Sokoły Górskie w powiecie piskim w interpretacji materiałów kartograficznych i zdjęć lotniczych. 1. lata 30. XX wieku; 2. 1967 rok; 3. 2017 rok. (oprac. A. Majewska na podstawie Topographische Karte 1:25 000, arkusz: Kosuchen, 2498/2598, 1936; fotogrametryczne zdjęcie lotnicze - sygnatura 7_9925, data wykonania: 20.07.1967, zasób CODGiK; ortofotomapa (2015) - www.geoportal.gov.pl). 
wschodu (ryc. 2) oraz bardziej rozbudowany, ze względu na bliskość granicy Prus Wschodnich, system fortyfikacji polowych znajdujący się ok. 500 metrów na południe od centrum Sokołów Górskich.

Teren wsi wchodzi w obręb obszaru AZP nr 29-76. Niestety, nie przeprowadzono na nim dotąd badań powierzchniowych, które mogłyby doprowadzić do ujawnienia stanowisk archeologicznych. We wsi zachowały się liczne naziemne relikty dawnych zabudowań. Podczas badań terenowych dokumentacji poddano wybrane pozostałości XX-wiecznej zabudowy znajdujące się w południowej części siedliska, w sąsiedztwie funkcjonującego obecnie gospodarstwa wiejskiego. Wybór został podyktowany największą dostępnością terenową obiektów pod względem możliwości prowadzenia prospekcji powierzchniowej w ich obrębie i otoczeniu. ${ }^{8}$. Na podstawie kartowania sporządzono szkic sytuacyjny, wyróżniając na nim 6 głównych obiektów (ryc. 3). Porównano ich umiejscowienie do zabudowy miejscowości ukazanej na mapie z 1936 roku (Topographische Karte 1:25 000, arkusz: Kosuchen, 2498/2598, 1936), wskazując obiekty, które mogą im odpowiadać - zaznaczone na ryc. 2. Niezadowalająca kartometryczność archiwalnego materiału kartograficznego powoduje, że nie można jednoznacznie przyporządkować reliktów zidentyfikowanych w terenie do budynków schematycznie przedstawionych na mapie. Przynależały one zapewne do dwóch sąsiadujących ze sobą zagród wiejskich, co można argumentować tym, że obiekty 3, 4, 5 oraz 6 znajdują się na lekkim wyniesieniu - platformie ziemnej, której granica, przebiegająca za filarami bramy, ma charakter liniowy - może stanowić dawną granicę między zabudowaniami.

Pierwszym obiektem są relikty budynku mieszkalnego, usytuowanego w osi NE-SW. Na najlepiej zachowaną jego zachodnią część, poddaną szczegółowej dokumentacji składają się: ganek oraz ściana frontowa. Centralnie usytuowany ganek wysunięty jest przed lico muru o ok. 2 m. Zbudowany został na ławie fundamentowej murowanej z kamienia polnego - naturalnie obtoczonych głazów narzutowych (widoczne w uszkodzonej części - ryc. 4). Wykończenie zewnętrzne fundamentu to zaprawa cementowa. Ściany ganku w górnej części również są konstrukcji cementowej. Całkowita wysokość ścian wynosi 1,45 m (mierzona od powierzchni gruntu w części frontalnej). W części bocznej wysokość jest mniejsza, tak samo wysokość ściany frontowej budynku, co spowodowane jest zachodzącymi procesami denudacji, a w związku z tym naturalnej depozycji materiału o charakterze roślinno-gruzowym, głównie pochodzącym $\mathrm{z}$ wietrzejących reliktów muru budowli i gnijącego materiału organicznego - roślinnego. Na omawiany ganek prowadzą usytuowane centralnie schody, na które składają się trzy

\footnotetext{
${ }^{8}$ Badaniami terenowymi nie udało się objąć oznaczonego na planie sytuacyjnym cmentarza ewangelickiego znajdującego się na terenie lasu, do którego obowiązywał zakaz wstępu (oznaczenie tablicą).
} 


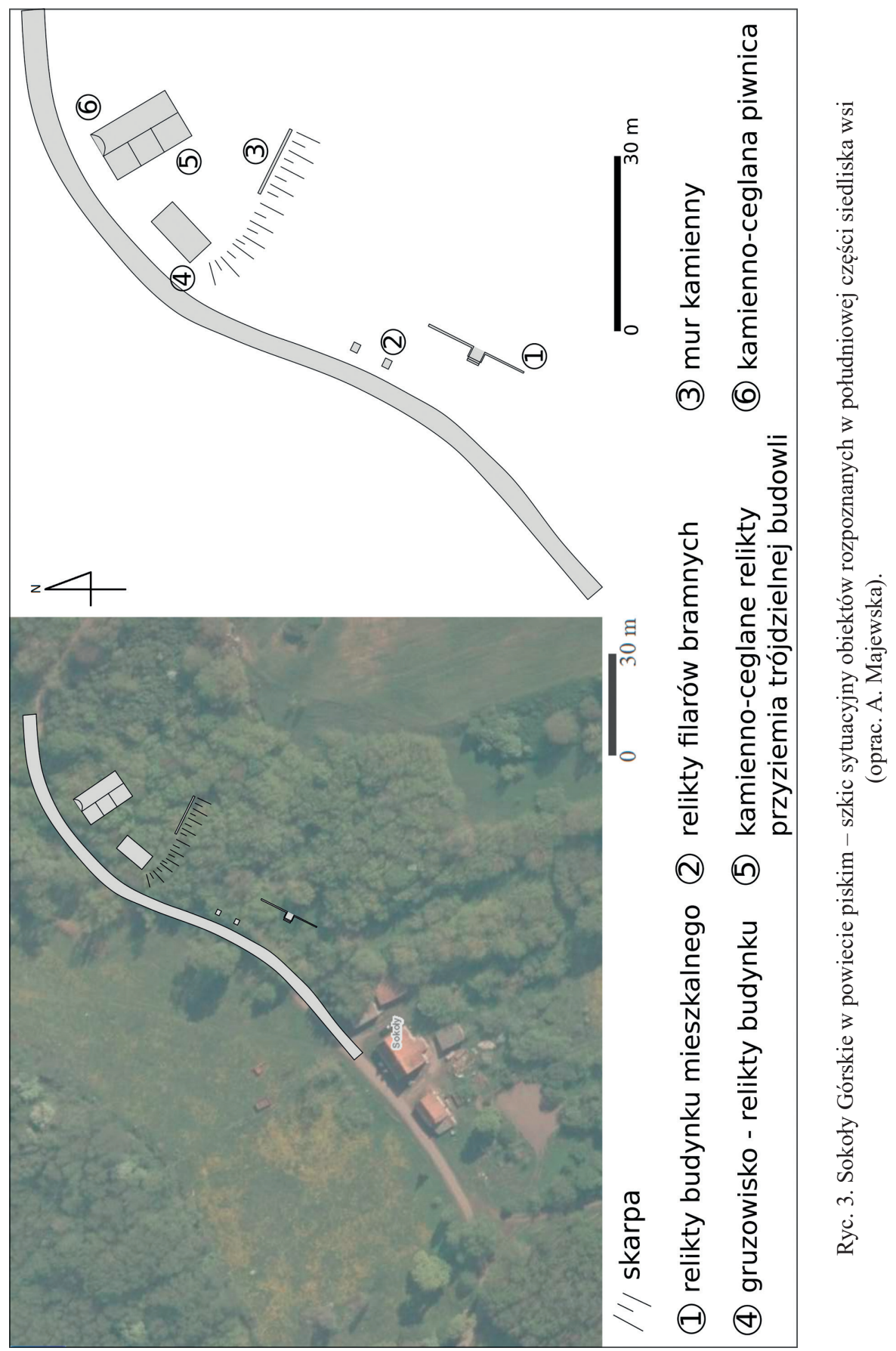



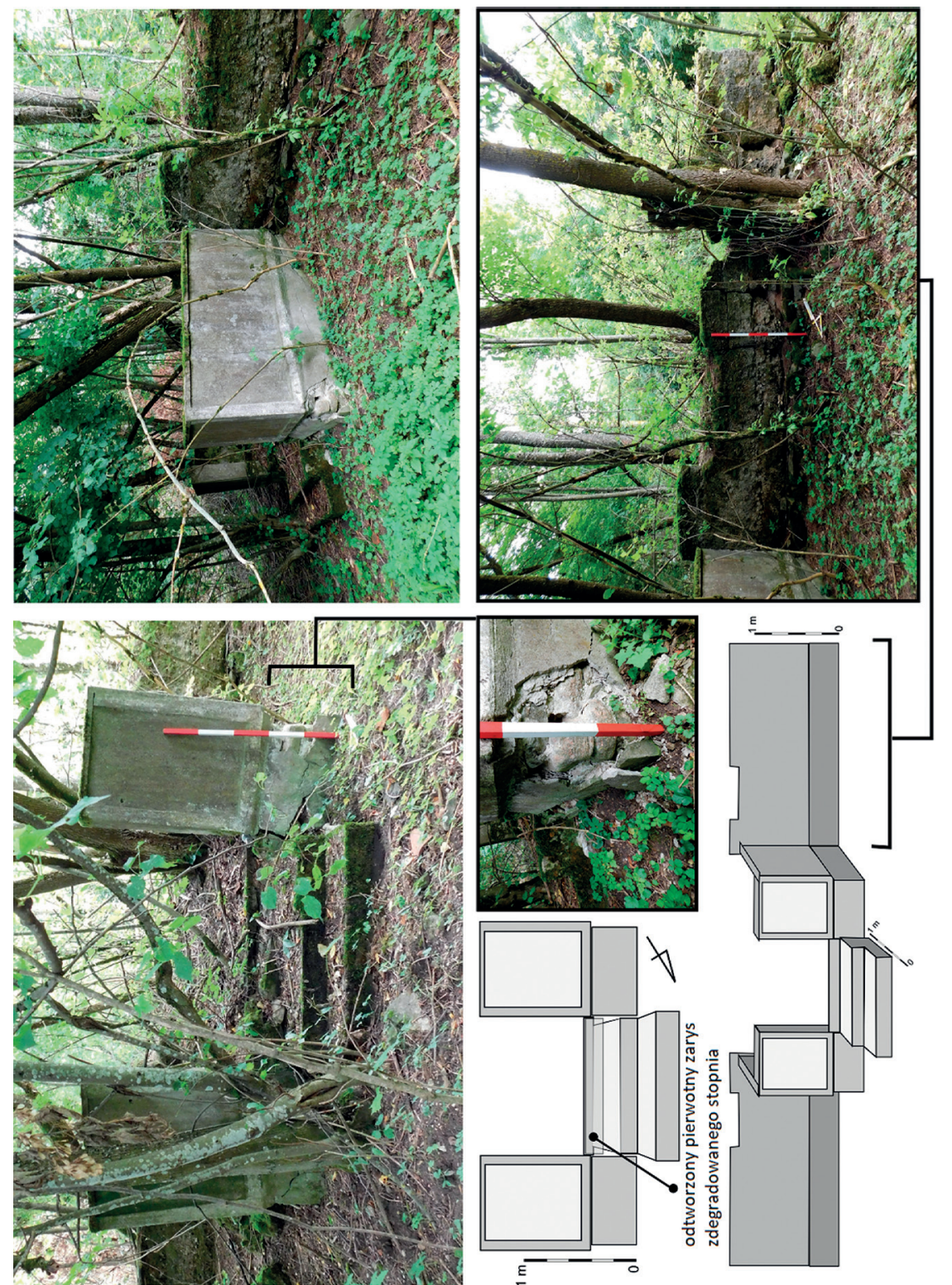

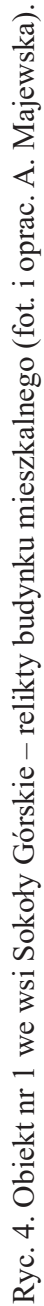


stopnie - najwyższy jest najbardziej zdegradowany, w wyniku czego uskok uległ cofnięciu. Schody również wymurowano z materiału kamiennego (wysokość stopnia ok. $0,15 \mathrm{~m}$, szerokość ok. $0,3 \mathrm{~m}$ ). W górnej części ganku nie zarejestrowano elementów, które mogłyby świadczyć o tym, że był on niegdyś zadaszony. Ściana frontowa budynku wymurowana została z kamienia - jej maksymalna wysokość wynosi ok. 1,3 m. W wyszczerbionym murze po obu stronach ganku zarysowane są zagłębienia po otworach okiennych. Nie można określić szczegółów dalszej części obiektu ponieważ stwierdzono jej daleko posuniętą degradację.

Do gospodarstwa $\mathrm{z}$ budynkiem przybliżonym $\mathrm{w}$ powyższym opisie prowadził wjazd bramny, po którym pozostały relikty filarów (obiekt nr 2). Jeden zachował się jedynie szczątkowo, drugi natomiast w stanie stosunkowo dobrym. Murowany z kamienia (poddanego obróbce mechanicznej) filar o prostokątnym narysie ma wysokość ok. 1,43 m (zwieńczenie zniszczone). Zarejestrowano jeden, dolny metalowy hak zawiasy bramnej (ryc. 5). Trzecim zarejestrowanym obiektem jest kamienny, niski murek. Jego pierwotnej funkcji nie udało się ustalić. Czwarty obiekt to zawalisko niewielkiego budynku, w którym trudno wyróżnić pierwotny układ pomieszczeń o ile podział występował. Wnętrze jest zagruzowane. Dwa większe, przylegające do siebie obiekty zarejestrowano w północnej części badanego terenu. Pierwszy z nich (obiekt nr 5) stanowią
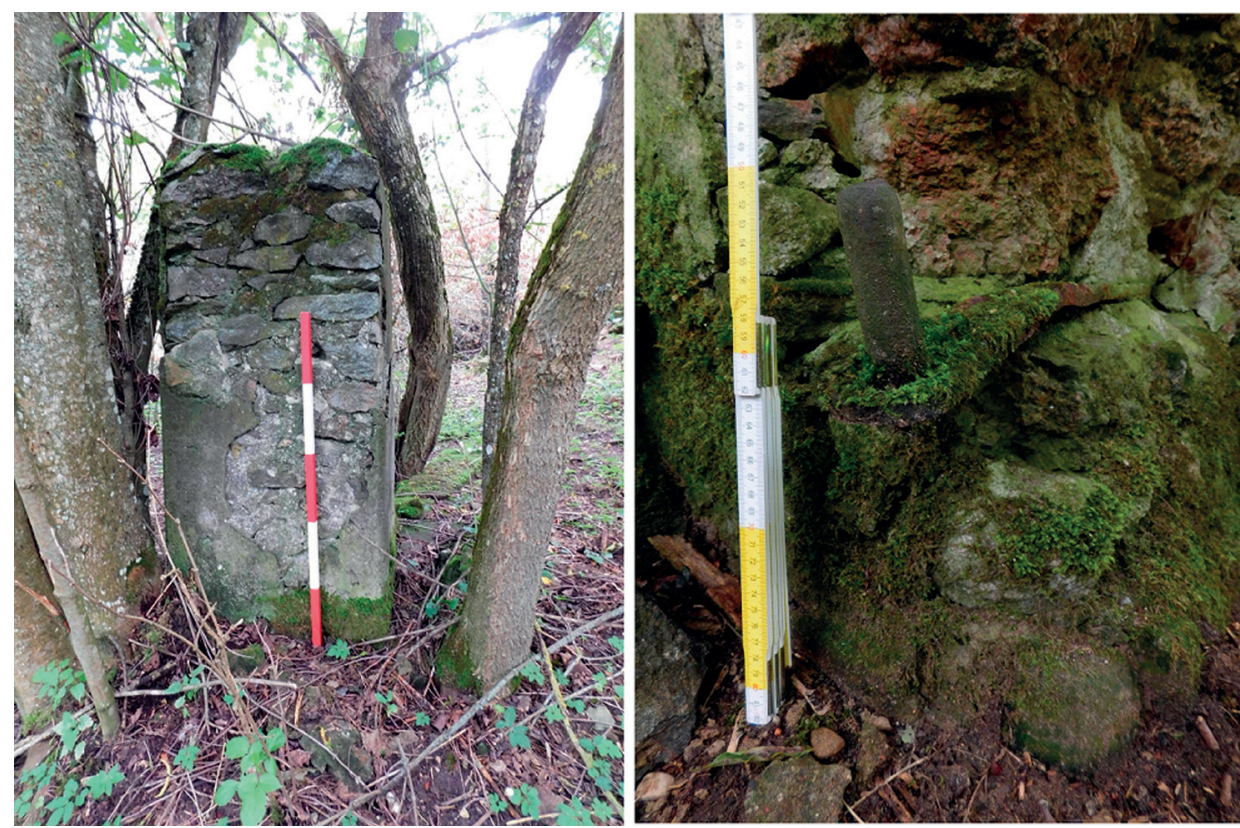

Ryc. 5. Obiekt nr 2 we wsi Sokoły Górskie - filar bramny (fot. i oprac. A. Majewska). 

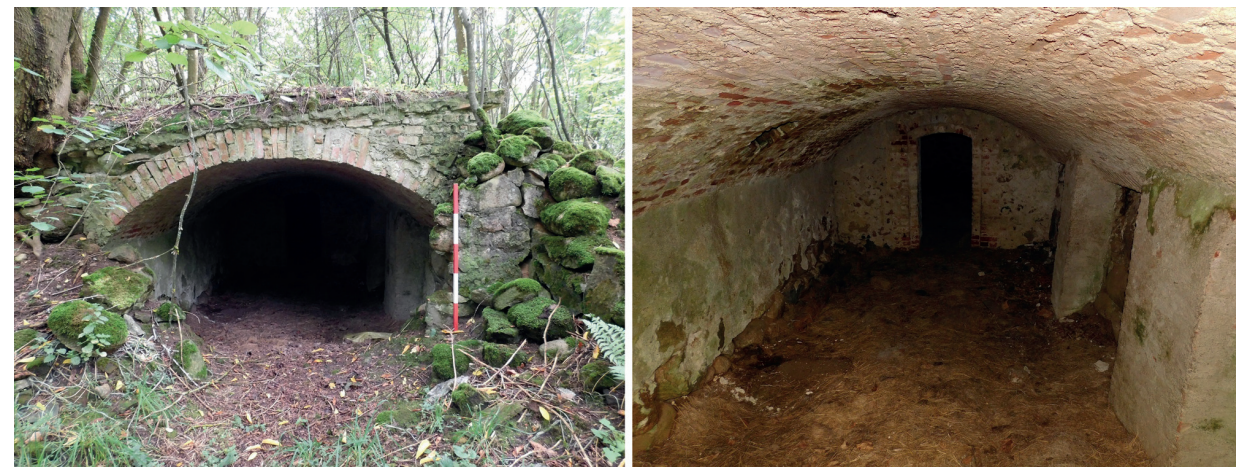

Ryc. 6. Obiekt nr 3 we wsi Sokoły Górskie - lodownia (fot. i oprac. A. Majewska).

pozostałości stosunkowo dużego budynku, którego wnętrze w przyziemiu było podzielone na co najmniej trzy pomieszczenia. Dobrze czytelnymi reliktami ścian są ich podstawy murowane z głazów narzutowych. Ostatnim, bardzo dobrze zachowanym obiektem jest tzw. lodownia, w podstawie murowana z kamienia z łukowym sklepieniem ceglanym - odcinkowym (ryc. 6). Podzielona jest w połowie długości na dwa pomieszczenia, w górnej części została wyposażona $\mathrm{w}$ otwory wentylacyjne.

Zadokumentowany in situ materiał ruchomy zarejestrowany został w różnych miejscach na kartowanej powierzchni opuszczonych gospodarstw. Najliczniej występowały małe fragmenty różnego rodzaju współczesnego materiału ceramicznego i dachówek. Największą uwagę poświęcono dwóm artefaktom, które zadokumentowano na skarpie zaznaczonej na szkicu poglądowym terenu badań (ryc. 3). Być może stanowiła ona również miejsce wysypiskowe, ponieważ nagromadzenie na powierzchni różnego rodzaju fragmentów pokruszonych cegieł, dachówek, szkła, ceramiki i innych odpadów budowlanych i użytkowych było tam największe. Rozpoznaniu materiału na powierzchni sprzyjał w tym miejscu brak roślinności. Gleba tylko fragmentarycznie pokryta była ściółką (głównie z obumarłych części drzew i krzewów). Intensywne opady deszczu, które dotknęły teren badań przed dokonaniem prospekcji, przyczyniły się również do intensyfikacji procesów wymywania, skutkujących możliwością lepszego zaobserwowania materiału pochodzenia nieorganicznego na powierzchni gruntu.

W tym miejscu zadokumentowano silnie skorodowany płaski talerz metalowy, emaliowany na biało, o średnicy ok. $16 \mathrm{~cm}$ (ryc. 7), który można wydatować na lata 50.-60. XX wieku9. Ten popularny w latach powojennych przed-

\footnotetext{
${ }^{9}$ Nie wyklucza to jednak starszej genezy przedmiotu (podobną formę i stan zachowania reprezentują np. miski i kubki żelazne odkryte podczas badań drugowojennego obozu - Waldlager Borek w Chełmnie - zob. Gołub 2012: 100-101, 108).
} 

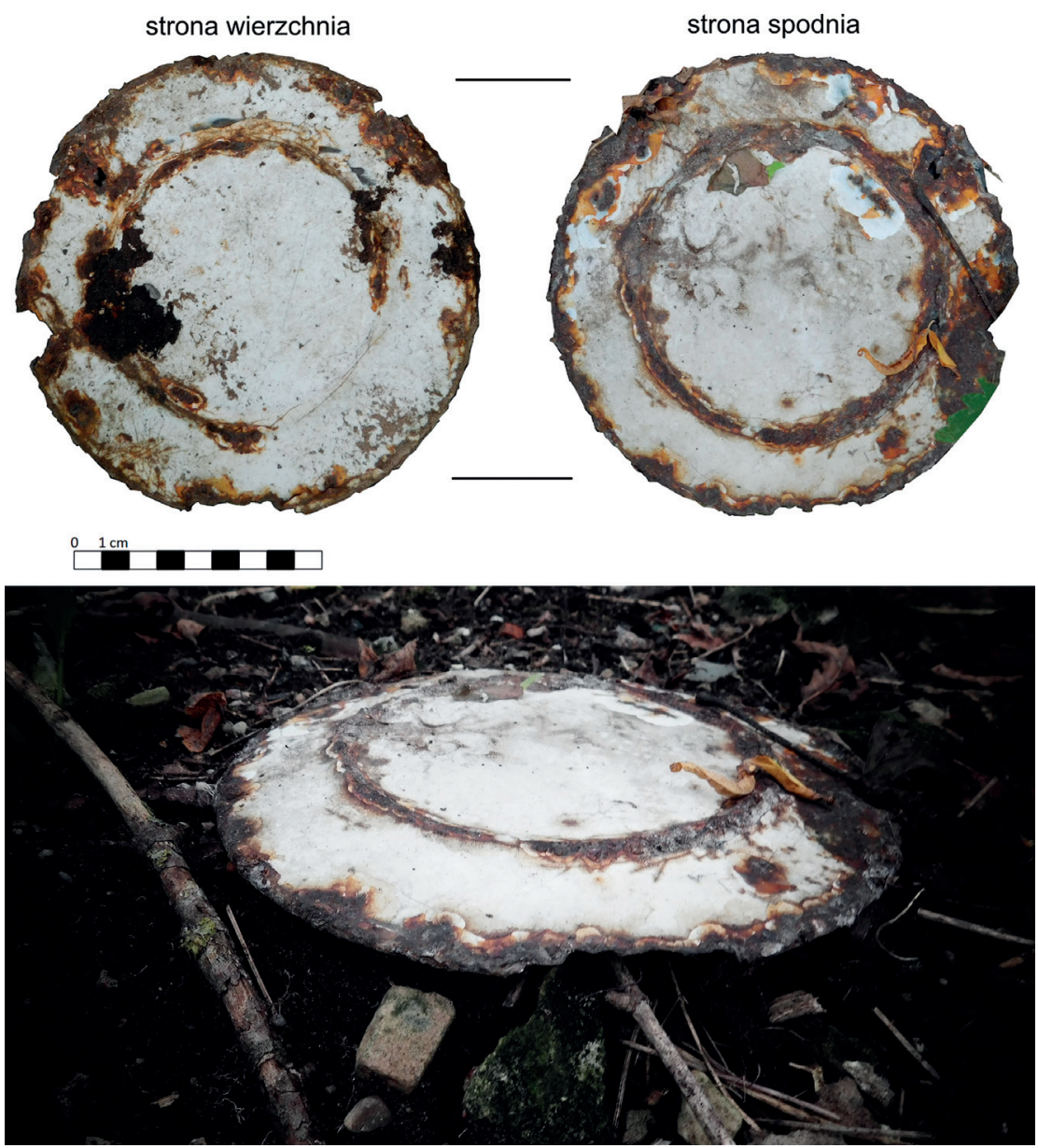

Ryc. 7. Zadokumentowany in situ emaliowany metalowy talerz (fot. i oprac. A. Majewska).

miot codziennego użytku może się wiązać $\mathrm{z}$ ostatnimi latami funkcjonowania gospodarstwa, na terenie którego się znajduje lub mógł on zostać tam wyrzucony z innymi odpadami w okresie późniejszym, już po opuszczeniu zagrody.

Drugim artefaktem zadokumentowanym in situ jest fragment porcelany z II poł. XIX lub z I poł. XX wieku. Jest nim odłamek niewielkiego przedmiotu, np. kubka - gładka część brzuśca z wylewem. Wymiary fragmentu to ok. $4,6 \times 4,2 \mathrm{~cm}$. Przedstawione są na nim trzy dziewczynki spoglądające w tym samym kierunku, w kolorowych sukienkach, jedna z nich trzyma lalkę (ryc. 8). Krawędź wylewu zdobiona jest oliwkowozieloną farbą. Wizerunek znajdujący się na porcelanie jest tożsamy (z minimalnymi odstępstwami) ze wzorem zdo- 
biącym niemiecki porcelanowy zestaw do zabawy dla dzieci, składający się z filiżanek ze spodeczkami, cukiernicy, dzbanka na mleko, dzbanka do herbaty, talerzyków deserowych, który według informacji amerykańskiego sprzedawcy antyków (Down The Road Antiques - Pensylwania - portal RubyLane.com) datowany jest na 1910 rok (ryc. 9). Z pewnością formy poszczególnych elementów zestawu różniły się szczegółami w zależności od danej edycji, o czym świadczy fotografia przedstawiająca datowany według jej autora na 1900 rok komplet $\mathrm{z}$ takim samym motywem, ale $\mathrm{w}$ nieco odmiennej aranżacji - m.in. inne kształty filiżanek i dzbanka oraz zdobienia ich wylewów (ryc. 9). Fragment ceramiki zinwentaryzowany na terenie siedliska w Sokołach Górskich można zatem z dużym prawdopodobieństwem łączyć z przedwojennym okresem funkcjonowania gospodarstwa, tym bardziej, że porcelana według pozyskanych informacji, jest produkcji niemieckiej (na podstawie sygnatur), a więc wiąże się przez to $\mathrm{z}$ okresem istnienia Prus Wschodnich. Obecność na stanowisku badawczym zarówno obszernej lodowni, jak i fragmentu z zapewne kosztownego dziecięcego zestawu do herbaty, wskazuje na zamieszkiwanie w tym miejscu

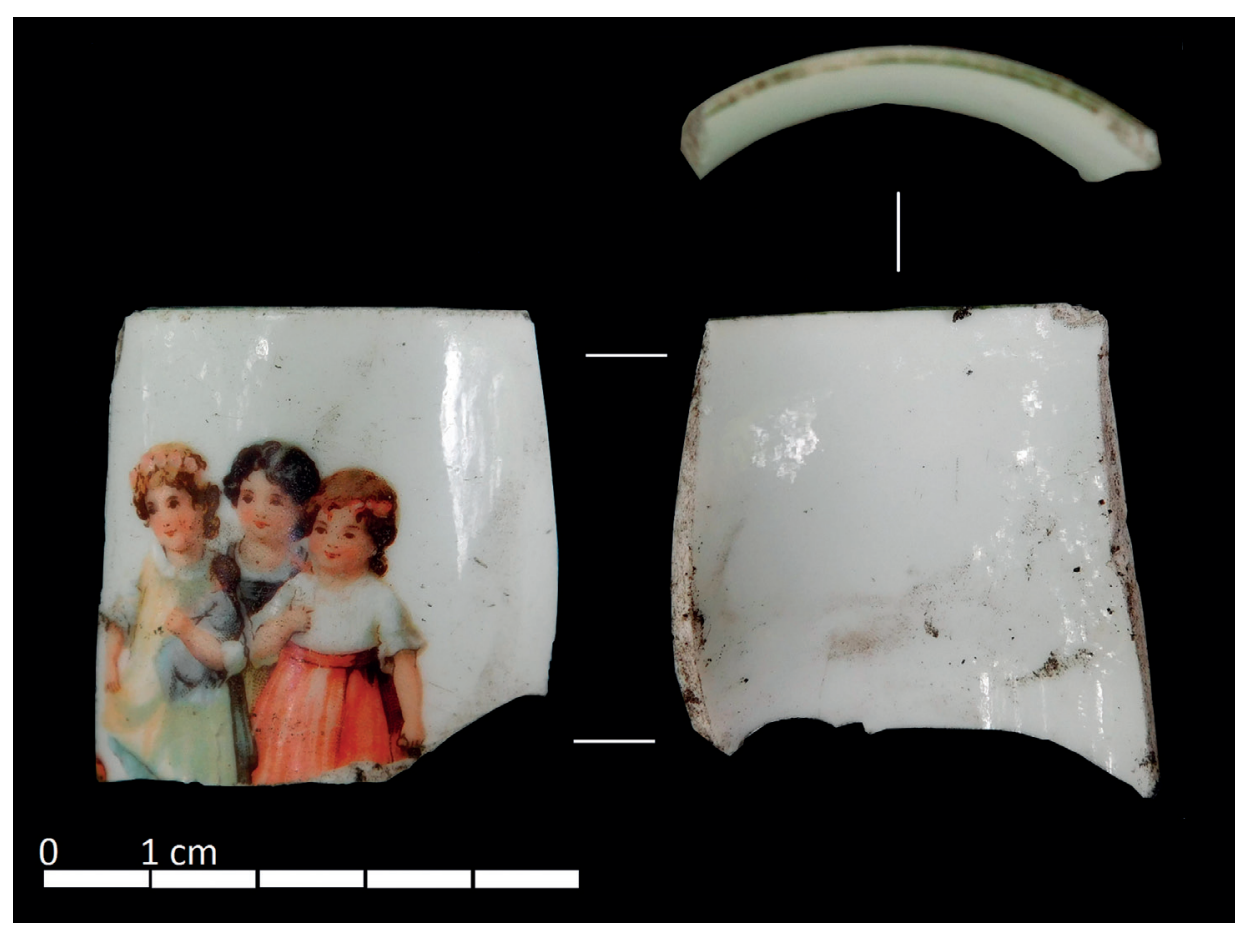

Ryc. 8. Fragment porcelany z przedstawieniem dzieci. Przedmiot zadokumentowany in situ (fot. i oprac. A. Majewska). 

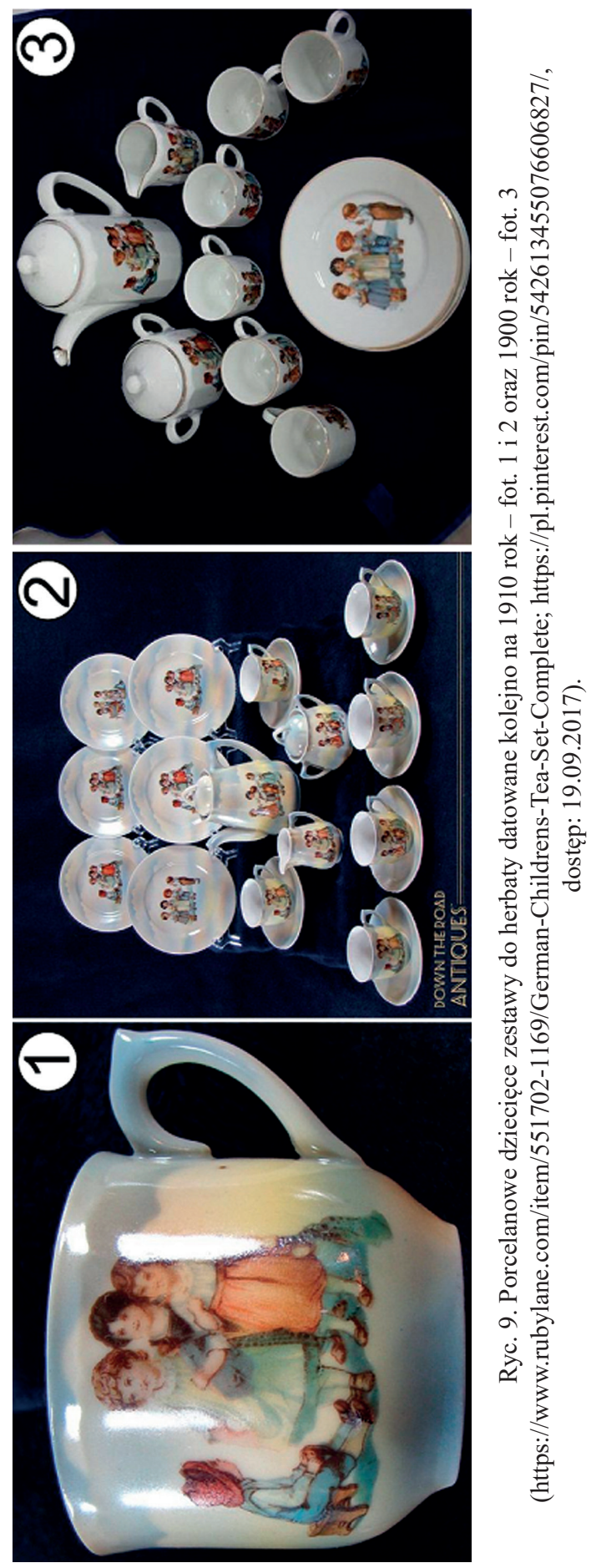
na początku XX wieku osób o ponadprzeciętnym statusie materialnym. Można się jedynie domyślać, czy właściciele gospodarstwa byli także założycielami i/lub użytkownikami elektrowni, niegdyś działającej na pobliskim wzniesieniu. Historie odczytywane teraz przez pryzmat materialnych reliktów $\mathrm{i}$ ich własnych mikrohistorii, dopełniają wciąż żywych, jak i historycznych przekazów na temat osadnictwa mazurskiego pogranicza.

\section{Podsumowanie}

Koncepcja interdyscyplinarnej analizy reliktów zanikłego osadnictwa mazurskiego wynika z ważkości tematyki współczesnych przemian krajobrazów Polski, w tym struktur osadniczych i dziedzictwa materialnego. Szczególnie interesujące zmiany dotyczą terenów, które w XX wieku zostały dotknięte gwałtowną depopulacją, tak jak miało to miejsce na pograniczu mazursko-mazowieckim. Zakres przedmiotowy podjętych przez autorkę analiz obejmujących miejscowości, w których zanik osadnictwa można współcześnie obserwować, pozwala skoncentrować się na szczegółowej analizie procesów destrukcji fizycznych elementów krajobrazu kulturowego. Połączenie ścieżki geograficznej, uwypuklającej aspekt przestrzenny obserwowanych zjawisk z dedukcją archeologiczną, skupiającą uwagę na poszczególnych obiektach kultury materialnej pozwala precyzyjniej i bardziej obrazowo rekonstruować obraz niedawnej przeszłości, która mimo upływu kilkudziesięciu lat, zdążyła już ulec znacznemu zatarciu. Nawet wówczas, kiedy znamy już z opracowań procesy obserwowane w otaczającym nas krajobrazie, tym ważniejsze powinny stać się mikrohistorie, uzupełniające powierzchowny i zgeneralizowany obraz przemian przestrzennych powodowanych czynnikami społeczno-politycznymi. Przykładem może tu być niewielka wioska, taka jak Sokoły Górskie, w której po zmroku zapada już niemal całkowita ciemność, zabierająca ze sobą historię mającej XV-wieczną genezę osady dawnego, a jednak także i współczesnego pogranicza.

Anna Majewska

Studentka archeologii Uniwersytetu Łódzkiego

ul. Narutowicza 65

90-131 Łódź

e-mail: anna.majewska@op.pl 


\section{Bibliografia}

\section{Źródła}

Fotogrametryczne zdjęcie lotnicze - sygnatura 7_9925, data wykonania: 20.07.1967, zasób Centralnego Ośrodka Dokumentacji Geodezyjnej i Kartograficznej, Warszawa.

Topographische Karte, 1:25 000, arkusz: Kosuchen, 2498/2598, 1936, źródło: http:// igrek.amzp.pl/details.php?id=5174 (dostęp: 19.09.2017).

\section{Opracowania}

Arnold S. (1951), Geografia historyczna Polski, Państwowe Wydawnictwo Naukowe, Warszawa.

Aston M. (1985), Interpreting the landscape. Landscape archaeology and local history, Routledge, London-New York.

Bailey G. (2007), Time Perspectives, Palimpsests and the Archaeology of Time, „Journal of Anthropological Archaeology", vol. 26, s. 198-223.

Beresford M. (1954), The lost villages of England, Sutton Publishing, London.

Beresford M., Hurst J. (1972), Deserted Medieval Villages: Studies, Lutterworth Press, Guildford.

Białuński G. (1993), Z dziejów osadnictwa Krainy Wielkich Jezior Mazurskich: pochodzenie osadników na przykładzie starostwa leckiego (giżyckiego) w XVI-XVII w., „Komunikaty Mazursko-Warmińskie”, nr 3, s. 391-401.

Białuński G. (2002), Kolonizacja Wielkiej Puszczy (do 1568 roku) - starostwa piskie, etckie, straduńskie zelkowskie $i$ węgoborskie (węgorzewskie), Ośrodek Badań Naukowych im. Wojciecha Kętrzyńskiego w Olsztynie, Olsztyn.

Chlebowski B., Walewski Wł. (red.) (1890), Słownik geograficzny Królestwa Polskiego i innych krajów słowiańskich, t. XI, Warszawa.

Ciołkosz A., Miszalski J., Olędzki J.R. (1999), Interpretacja zdjęć lotniczych, Wydawnictwo Naukowe PWN, Warszawa.

Figlus T. (2016), Problem osad zaginionych na gruncie badań geograficznohistorycznych. Próba konceptualizacji teoretycznej $i$ wybrane zagadnienia metodyczno-empiryczne, „Acta Universitatis Lodziensis. Folia Geographica Socio-Oeconomica", nr 25, s. 83-108.

Fokt K. (2016), Villa deserta, deperdita, oblita. Różne oblicza wsi zaginionej: uwagi wstępne, [w:] P. Nocuń, A. Przybyła-Dumin, K. Fokt (red.), Wieś zaginiona. Stan i perspektywy badań, Muzeum „Górnośląski Park Etnograficzny w Chorzowie”, Chorzów, s. 9-16.

Fokt K., Legut-Pintal M. (2016), Zanikłe wsie Wzgórz Strzelińskich: stan i perspektywy badań, [w:] P. Nocuń, A. Przybyła-Dumin, K. Fokt (red.), Wieś zaginiona. Stan i perspektywy badań, Muzeum „Górnośląski Park Etnograficzny w Chorzowie", Chorzów, s. 113-145.

Funk L. (2013), Zaniklé osidleni po roce 1945 jako archeologický pramen, Západočeská univerzita $v$ Plzni, Plzeň, maszynopis rozprawy doktorskiej. 
Gołub S. (2012), Katalog zabytków, [w:] K. Mart, A. Rybak, S. Gołub (red.), Las Borek $w$ Chetmnie. Zapomniane miejsce zbrodni hitlerowskich. Wyniki badań archeologicznych i historycznych w miejscu kaźni, Muzeum Ziemi Chełmskiej im. Wiktora Ambroziewicza, Chełm, s. 81-157.

Karsvall O. (2013), Retrogressiv metod. En översikt med exempel från historisk geografi och agrarhistoria , „Historisk Tidskrift”, no. 133(3), s. 411-435.

Kijowska J., Kijowski A., Rączkowski W. (2011), Krajobraz i polityka - wybrane aspekty wptywu decyzji politycznych na zmiany krajobrazu w Polsce, „Prace Komisji Krajobrazu Kulturowego", nr 15, s. 103-115.

Kobiałka D. (2016), UrbEx: archeologiczny flâneuryzm a multitemporalność dziedzictwa, „Biografia Archeologii”, nr 2(1), s. 3-12.

Korycka W. (red.) (1970), Pisz. Z dziejów miasta i powiatu, Wydawnictwo „Pojezierze”, Olsztyn.

Kostrzewa A. (2007), Wysiedlenie Niemców z powiatu giżyckiego w latach 1945-1948, „Komunikaty Mazursko-Warmińskie”, nr 1, s. 39-55.

Koter M. (1994), Od fizjonomii do morfogenezy i morfologii porównawczej. Podstawowe zagadnienia teoretyczne morfologii miast, [w:] M. Koter, J. Tkocz (red.), Zagadnienia geografii historycznej osadnictwa w Polsce, Wydawnictwo UMK, Łódź-Toruń, s. 23-32.

Kowalczyk E. (2003), Na marginesie kolonizacji „,Wielkiej Puszczy”, „Komunikaty Mazursko-Warmińskie", nr 3, s. 369-374.

Marciniak-Kajzer A. (2016), Późnośredniowieczne wsie w świetle badań archeologicznych, ,Zeszyty Wiejskie”, nr 22, s. 791-800.

Matuszewski E. (1980), Liczebny stan szkolnictwa mazurskiego w 1800 roku, „Komunikaty Mazursko-Warmińskie", nr 1, s. 17-39.

Sheppard T. (1912), The Lost Towns of the Yorkshire Coast and Other Chapters Bearing Upon the Geography of the District, Browns' Savile Press, London.

Szmytkie R. (2008), Nieistniejace wsie w Sudetach, [w:] M. Kulesza (red.), Czas i przestrzeń w naukach geograficznych. Wybrane problemy geografii historycznej, Wydawnictwo Uniwersytetu Łódzkiego, Łódź, s. 225-242.

Sztampke M. (red.) (2014), Laserowi odkrywcy - nieinwazyjne badanie i dokumentowanie obiektów archeologicznych i historycznych województwa świętokrzyskiego, Fundacja Centrum GeoHistorii, Stare Babice.

Szulc H. (1995), Morfogeneza osiedli wiejskich w Polsce, „Prace Geograficzne”, nr 163, Wrocław.

Szultka Z. (2004), Dynamika zaludnienia Prus Książęcych (Wschodnich) w XVIII wie$k u$, „Komunikaty Mazursko-Warmińskie”, nr 2, s. 147-162.

Vařeka P., Buraćinská M., Rožmberský P., Veselá R, (2008), Archeologie zaniklých středověkých vesnic na Rokycansku II, Západočeská univerzita v Plzni, Plzeň.

Vařeka P., Rožmberský P. (red.) (2009), Středověká Krajina na Středni Úslavě I, Vydalo nakl. Petr Mikota, Plzeň.

Zestawienie znaków topograficznych... (1925), Zestawienie znaków topograficznych map austriackich, niemieckich i rosyjskich, Wojskowy Instytut Geograficzny. 


\section{Źródła internetowe}

Bank Danych o Lasach: https://www.bdl.lasy.gov.pl/portal/mapy (dostęp: 23.10.2017).

Geoportal: www.geoportal.gov.pl (dostęp: 15.03.2017).

Pinterest: https://pl.pinterest.com/pin/542613455076606827/ (dostęp: 19.09.2017).

RubyLane: https://www.rubylane.com/item/551702-1169/German-Childrens-Tea-Set-Complete(dostęp: 19.09.2017).

\section{SumMary}

\section{RELICTS OF THE DESERTED VILLAGES AT THE MASURIAN-MAZOVIAN BORDERLAND. INTERDISCIPLINARY RESEARCH PROJECT}

The paper presents the proposal for an interdisciplinary, humanistically oriented analysis of extinct settlements on the example of the results of the author's research project realized on the territory of the Pisz county in the Warmińsko-Mazurskie voivodship. The project, embedded in the current research trend on the transformations of the contemporary landscape, was focused on the analysis of the relics of the 20th century extinct settlement structures and their material heritage. The research topic was based on the compilation of theoretical assumptions of historical geography (e.g. Koter 1994; Figlus 2016) and fieldwork methodology developed through historical archeology, including contemporary archeology (e.g. Vařeka et al. 2008). The results of the study were published in the article on the case study of the disappearing village - Sokoły Górskie. The research results presented both in the form of cartographic synthesis and field surveying studies conducted within landscape structures show the large quantitative and qualitative dimension of transformations that were taking place as a result of violent socioeconomic changes of the 20th century (e.g. rapid depopulation), which were the effect of global armed conflicts. 